\title{
Pengaruh Faktor Budaya, Sosial, Personal Dan Psikologis Mahasiswa IAIN Ponorogo Terhadap Keputusan Menabung Di Perbankan Syariah
}

\author{
Rindi Antika \\ Institut Agama Islam Negeri Ponorogo \\ E-mail: antikarindi980@gmail.com \\ Rohmawati Solikhah \\ Institut Agama Islam Yasni Bungo \\ E-mail: rohmawatisolikhah931101@gmail.com
}

\begin{abstract}
Abstrak
Penelitian menggunakan metode kuantitatif. Analisis data menggunakan regresi linier sederhana dan analisis regresi linier berganda. Metode pengolahan data menggunakan program aplikasi IBM SPSS Statistic 21. Sedangkan dalam pengumpulan data, peneliti menggunakan probability sampling dengan menggunakan teknik simple random sampling. Populasi dalam penelitian ini 10,349 mahasiswa IAIN Ponorogo dan sampel yang digunakan 100 mahasiswa. Hasil penelitian menunjukkan bahwa variabel personal tidak berpengaruh positif terhadap keputusan menabung. Terlihat bahwa variabel personal mempunyai nilai thitung 2,330> $t$ tabel 1,984 dan signifikansi 0,022 lebih kecil dari 0,05. Hal ini dikarenakan bahwa pengalaman mahasiswa dalam menggunakan bank syariah masih sangat sedikit. Oleh karena itu pihak perbankan syariah melakukan peningkatan promosi supaya banyak peminatnya.
\end{abstract}

Kata Kunci: Perilaku Konsumen, Keputusan Pembelian

\begin{abstract}
Abstrak
This research uses quantitative methods. Data analysis used simple linear regression and multiple linear regression analysis. Methods of data processing using the IBM SPSS Statistic 21 application program. While in data collection, researchers used probability sampling using simple random sampling technique. The population in this study was 10,349 students of IAIN Ponorogo and the sample used was 100 students. The results showed that personal variables had no positive effect on saving decisions. It can be seen that the personal variable has a tcount of 2,330> 1,984 and a significance of 0.022 is less than 0.05 . This is because the student experience in using Islamic banks is still very little. Therefore, the Islamic banking sector has increased its promotion so that there are many enthusiasts.
\end{abstract}

Keywords: Consumer Behavior, Purchase Decision

\section{A. Pendahuluan}

Sejarah keberadaan bank syariah dalam sistem perbankan Indonesia sebenarnya telah dikembangkan sejak tahun 1992, ditandai dengan berdirinya bank Muamalat, dan sejalan dengan diberlakukannya Undang-Undang No. Tahun 1992 Tentang Perbankan. Perkembangan sistem keuangan syariah ini semakin kuat setelah ditetapkannya Undang-Undang No.10 Tahun 1998, dalam undang- undang tersebut 
Rindi Antika, Rohmawati Solikhah : Pengaruh Pembiayaan Murabahah ...

diatur secara rinci landasan hukum serta jenis-jenis usaha yang dapat dioperasikan dan diimplementasikan oleh bank syariah. Undang-undang tersebut memberikan arahan bagi bank konvensional untuk membuka cabang syariah atau mengkonversikan secara total menjadi bank syariah ${ }^{1}$. Dan Undang-Undang No. 23 Tahun 1999, dan Undang-Undang No.3 Tahun 2004 tetang Bank Indonesia.

Setelah keluarnya fatwa Majelis Ulama Indonesia (MUI) pada akhir 2003 tentang keharaman bunga uang pada bank konvensional, sehingga masyarakat mengalihkan dana mereka yang awalnya diinvestasikan pada bank-bank konvensional kepada bankbank syariah.

Perkembangan bank syariah di Indonesia tergolong pesat. Dalam waktu kurang dari 20 tahun banyak bank-bank yang semula bersifat konvensional akhirnya membuka cabang perbankan yang bersifat syariah. Perusahaan-perusahaan perbankan tersebut bukanlah hanya sekedar mencoba untuk mengembangkan prinsip syariah di Indonesia, tetapi faktor yang lebih penting adalah permintaan konsumen untuk dibentuknya perbankan syariah.

Menurut Kotler (2015) faktor pertama yang mempengaruhi perilaku pengambilan keputusan adalah faktor kebudayaan. Faktor kebudayaan merupakan penentu keinginan dan perilaku yang paling mendasar untuk mendapatkan nilai, persepsi, preferensi dan perilaku dari lembaga-lembaga penting lainnya. Faktor budaya meliputi kebudayaan, sub-budaya dan kelas sosial. ${ }^{2}$

Kepribadian sering diartikan sebagai karakteristik individual yang merupakan perpaduan dari sifat, tempramen, kemampuan umum dan bakat yang dalam perkembangannya dipengaruhi oleh interaksi individu dengan lingkungannya. Perilaku seseorang dalam membeli sesuatu juga dipengaruhi oleh faktor-faktor kepribadian dari konsumen yang bersangkutan. Faktor pribadi termasuk watak dasar seseorang terutama karakteristik dominan mereka. Meskipun kepribadian adalah salah satu konsep yang berguna dalam mempelajari perilaku konsumen, beberapa pemasar percaya bahwa kepribadian mempengaruhi jenis-jenis dan merek-merek produk yang dibeli. $^{3}$

Proses psikologi utama. Titik awal untuk memahami perilaku konsumen adalah model tanggapan. Pemasaran dan rangsangan lingkungan memasuki kesadaran konsumen. Satu perangkat proses psikologi berkombinasi dengan karakteristik konsumen tertentu untuk menghasilkan proses keputusan dan keputusan pembelian. Tugas pemasar adalah memahami apa yang terjadi dalam kesadaran konsumen antara datangnya rangsangan pemasaran luar dan keputusan pembelian akhir. Empat proses psikologi penting: motivasi, persepsi, pembelajaran dan memori mempengaruhi tanggapan konsumen terhadap berbagai tanggapan pemasaran. ${ }^{4}$

Pengalaman mahasiswa dalam menggunakan bank syariah masih sangat sedikit dikarenakan banyak mahasiswa yang belum menabung di perbankan syariah. Dengan latar belakang pendidikan yang berbasis Islam, diharapkan mahasiswa mempunyai

\footnotetext{
${ }^{1}$ Muhammad Syafi'I Antonio, Bank Syariah Dari Teori ke Praktik (Jakarta: Gema Insani, 2001), 26.

${ }^{2}$ Agung Suprayitno, "Pengaruh Faktor Budaya, Sosial, Pribadi dan Psikologis Konsumen Terhadap Pembelian Gado-Gado Boplo," Jurnal Agribisnis, No. 2 (2015), 201.

${ }^{3}$ Tatik Suryani, Perilaku Konsumen: Implikasi pada Strategi Pemasaran, (Yogyakarta: Graha Ilmu, 2012), 57.

${ }^{4}$ Ketut Indah P. dan Kastawan M., "Pengaruh Faktor Budaya, Sosial, Pribadi Psikologis dan Bauran Pemasaran Terhadap Keputusan Pembelian Kebaya Bordir pada Jegeg Ayu Boutique di Kuta", Jurnal Manajemen Unud, No. 11 (2015), 3622.
} 
Rindi Antika, Rohmawati Solikhah : Pengaruh Pembiayaan Murabahah ...

pemahaman tentang perbankan syariah, akan tetapi pada kenyataannya banyak mahasiswa yang mempunyai pemahaman berbeda dalam memandang perbankan syariah.

Dari segi pemasaran sudah banyak dilakukan strategi-strategi untuk mempromosikan produk-produk ke mahasiswa. Namun kenyataannya konsep bank konvensional sudah melekat pada mahasiswa IAIN Ponorogo. Sehingga masih banyak mahasiswa yang menggunakan jasa dari bank-bank konvensional daripada bank syariah. Ada beberapa jurusan terutama pada Fakultas Ekonomi dan Bisnis Islam yang mewajibkan mahasiswanya untuk memiliki rekening di bank syariah. Tetapi kenyataannya mahasiswa menggunakan produk dari perbankan syariah hanya sebagai formalitas karena diwajibkan saja.

Melihat kondisi tersebut maka penulis memilih objek mahasiswa IAIN Ponorogo untuk mengetahui sejauh mana pengaruh faktor budaya, sosial, personal dan psikologis mahasiswa terhadap keputusan menabung di perbankan syariah. Banyak sekali faktorfaktor yang bisa mempengaruhi untuk keputusan menabung dalam memilih lembaga keuangan (Bank/BPRS). Hal ini tentunya setiap individu nasabah memiliki referensi atau pengalaman yang bisa mempengaruhi keputusan mereka. Hal ini disebabkan karena masyarakat Indonesia memiliki budaya, agama dan suku yang sangat beraga.

Tujuan dari penelitian ini untuk mengetahui pengaruh yang signifikan antara variabel budaya, sosial, personal, dan psikologis mahasiswa IAIN Ponorogo terhadap keputusan menabung di perbankan syariah.

\section{B. Landasan Teori}

\section{Pengertian Keputusan Menabung}

Pengambilan keputusan konsumen memiliki sasaran atau perilaku yang ingin dicapai atau dipuaskan. Selanjutnya konsumen membuat keputusan mengenai perilaku yang ingin dilakukan untuk dapat memecahkan masalahnya. ${ }^{5}$

Menurut Kotler mengemukakan bahwa keputusan adalah sebuah proses pendekatan penyelesaian masalah yang terdiri dari pengenalan masalah, mencari informasi, beberapa penilaian alternatif, membuat keputusan membeli dan perilaku setelah membeli yang dilalui konsumen. Pengertian keputusan pembelian menurut Drumond yaitu mengidentifikasikan semua pilihan yang mungkin untuk memecahkan persoalan itu dan menilai pilihan-pilihan secara sistematis dan obyektif serta sasaran-sasarannya yang menentukan keuntungan serta kerugiannya masingmasing. ${ }^{6}$

William J. Santos (1993) menyebutkan bahwa keputusan pembelian untuk kebanyakan produk hanyalah suatu kegiatan rutin dalam arti kebutuhan akan cukup terpuaskan melalui pembelian ulang suatu produk yang sama. Namun apabila terjadi perubahan harga, produk dan pelayanan yang diterima maka konsumen tersebut mungkin tidak akan mengulang kembali keputusan pembeliannya dengan mempertimbangkan berbagai alternatif produk. ${ }^{7}$

Pengambilan keputusan merupakan sebuah proses kegiatan individu yang secara langsung sebelum mendapatkan dan menggunakan barang yang ditawarkan. Tahaptahap proses keputusan pembelian dapat digambarkan dalam sebuah model dibawah

\footnotetext{
${ }^{5}$ M. Anang Firmansyah, PERILAKU KONSUMEN (Sikap dan Pemasaran) (Yogyakarta: Deepublish, 2018), 26.

${ }^{6}$ Atin Yulaifah, "Pengaruh Budaya, Sosial, Pribadi, dan Psikologis Terhadap Keputusan Nasabah Dalam Memilih Bank Syariah", Skripsi (Jakarta: UIN Syarif Hidayatullah, 2011), 23.

${ }^{7}$ Usman Effendi, Psikologi Konsumen (Jakarta: PT. Rajagrafindo Persada, 2016), 247
} 
Rindi Antika, Rohmawati Solikhah : Pengaruh Pembiayaan Murabahah ...

ini :

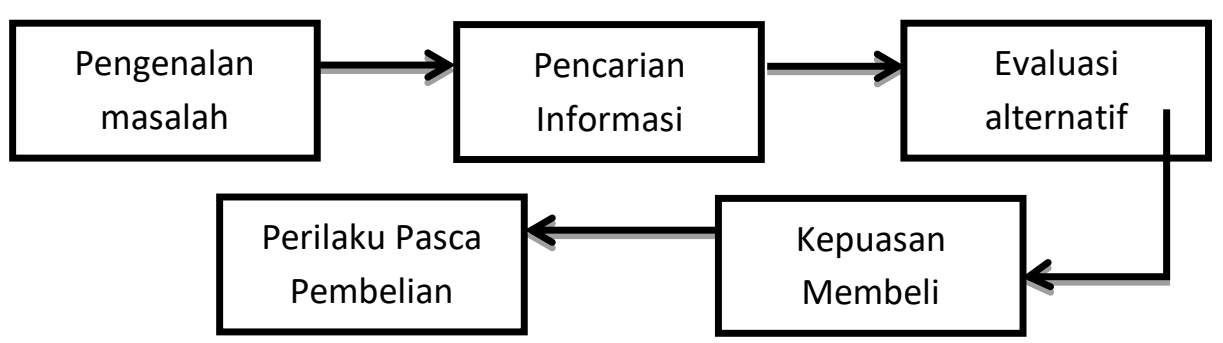

a. Pengenalan Masalah

Proses membeli dengan pengenalan masalah atau keadaan bahwa keinginan berbeda dengan kenyataan menimbulkan masalah pada pelanggan. Kebutuhan dapat digerakkan oleh keinginan dari dalam diri pembeli atau dari luar. ${ }^{8}$

b. Pencarian informasi

Konsumen mungkin tidak berusaha secara aktif dalam mencari informasi sehubungan dengan kebutuhannya. Seberapa jauh orang tersebut mencari informasi tergantung pada kuat lemahnya dorongan kebutuhan, banyaknya informasi yang dimiliki, kemudahan memperoleh informasi, tambahan dan kepuasan yang diperoleh dari kegiatan mencari informasi.

c. Evaluasi alternativ

Informasi yang didapat dari calon pembeli digunakan untuk memperoleh gambaran yang lebih jelas mengenai alternatif-alternatif yang dihadapinya serta daya tarik masing-masing alternatif.

d. Keputusan menabung

Produsen harus memahami bahwa konsumen berhak menangani informasi yang diperolehnya dengan membatasi alternatif- alternatif yang harus dipilih atau dievaluasi untuk menentukan produk mana yang akan dibeli.

e. Prilaku Pasca Menabung

Jika barang yang dibeli tidak memberikan kepuasan kepada pembeli, maka pembeli akan berfikir negatif terhadap merek barang tersebut bahkan mungkin akan menolak dari daftar pilihan. Sebaliknya bila konsumen mendapat kepuasan dari barang yang dibelinya maka keinginan untuk membeli terhadap merek barang tersebut cenderung untuk menjadi lebih kuat.

\section{Pengertian perilaku konsumen}

Perilaku konsumen merupakan suatu proses yang berkaitan erat dengan adanya suatu proses pembelian, pada saat itu konsumen melakukan aktivitas seperti melakukan penelitian dan pengevaluasian produk dan jasa (product and services). Perilaku konsumen merupakan sesuatu yang mendasari konsumen untuk membuat keputusan dalam pembelian. Perilaku konsumen adalah sebuah kegiatan yang berkaitan erat dengan proses pembelian suatu barang atau jasa. ${ }^{9}$

Ada beberapa definisi perilaku konsumen. Menurut Engel et al (1995), perilaku konsumen adalah tindakan yang langsung terlibat untuk mendapatkan, mengkonsumsi dan menghabiskan produk dan jasa termasuk proses keputusan yang mendahului dan

\footnotetext{
${ }^{8}$ Nugroho J. Setiadi, Perilaku Konsumen: Perspektif Kontemporer pada Motif, Tujuan dan Keinginan Konsumen (Jakarta: Predamedia Group, 2003), 345.

${ }_{9}^{9}$ Atin Yulaifah, "Pengaruh Budaya, Sosial, Pribadi, dan Psikologis Terhadap Keputusan Nasabah Dalam Memilih Bank Syariah", Skripsi (Jakarta: UIN Syarif Hidayatullah, 2011), 25.
} 
Rindi Antika, Rohmawati Solikhah : Pengaruh Pembiayaan Murabahah ...

mengikuti tindakan ini. Sementara itu, Loudon dan Bitta lebih menekankan perilaku konsumen sebagai suatu proses pengambilan keputusan. Mereka mengatakan bahwa perilaku konsumen adalah proses pengambilan keputusan yang mensyaratkan aktivitas individu untuk mengevaluasi, memperoleh, menggunakan, atau mengatur barang dan jasa. ${ }^{10}$

Berdasarkan pendapat yang dikemukakan oleh para ahli tersebut perilaku konsumen adalah proses dan aktivitas ketika seseorang berhubungan dengan pencarian, pemilihan, pembelian, penggunaan, serta pengevaluasian produk dan jasa demi memenuhi kebutuhan dan keinginan perilaku konsumen merupakan hal-hal yang mendasari konsumen untuk membuat keputusan pembelian.

1) Faktor-faktor yang mempengaruhi keputusan konsumen

Perilaku pembelian konsumen dipengaruhi oleh faktor- faktor budaya, sosial, pribadi dan psikologis sebagai berikut.

a) Faktor Budaya

Budaya dapat didefinisikan sebagai hasil kreativitas manusia dari satu generasi ke generasi berikutnya yang sangat menentukan bentuk perilaku dalam kehidupannya sebagai anggota masyarakat. Kebudayaan merupakan suatu hal yang kompleks yang meliputi ilmu pengetahuan, kepercayaan, seni, moral, adat, kebiasaan, dan normanorma yang berlaku pada masyarakat.

Flemming Hansen mengemukakan bahwa karakteristik budaya adalah: "culture is man-made, cultur is learned, culture is prescriptive, culture is sosially shared, culture are similiar but difference, culture is gratifying and persistent, culture is adaptive, culture is organized and integrated". (Kebudayaan adalah hasil karya manusia, proses belajar, mempunyai aturan/berpola, bagian dari masyarakat, menunjukkan kesamaan tertentu tetapi pula terdapat variansi-variansinya, pemenuhan kepuasan dan kemantapan atau ketetapan, penyesuaian, terorganisasi dan terintegrasi secara keseluruhan).

Menurut Kotler (2015) faktor pertama yang mempengaruhi perilaku pengambilan keputusan adalah faktor kebudayaan. Faktor kebudayaan merupakan penentu keinginan dan perilaku yang paling mendasar untuk mendapatkan nilai, persepsi, preferensi dan perilaku dari lembaga-lembaga penting lainnya. Faktor budaya meliputi kebudayaan, sub-budaya dan kelas sosial. ${ }^{11}$

Budaya, sub-budaya dan kelas sosial sangat penting bagi perilaku pembelian. Budaya merupakan penentu keinginan dan perilaku paling dasar. Anak-anak yang sedang bertumbuh mendapatkan seperangkat nilai, persepsi, prefensi, dan perilaku dari keluarga dan lembaga- lembaga lainnya. Anak-anak yang dibesarkan di Amerika Serikat sangat terpengaruh oleh nilai- nilai sebagai berikut: prestasi dan keberhasilan, aktivitas, efisiensi dan keraktisan, kemajuan, kenikmatan materi, individualisme, kebebasan, kenikmatan eksternal, humanism, dan berjiwa muda.

Sub-budaya mencakup kebangsaan, agama, kelompok, ras, dan wilayah geografis. Tiap kultur mempunyai subkultur yang lebih kecil atau kelompok orang dengan system nilai yang sama berdasarkan pengalaman dan situasi hidup yang sama. ${ }^{12}$

Kelas sosial memiliki beberapa ciri. Pertama, orang yang dalam kelas sosial yang sama cenderung berperilaku lebih seragam daripada orang-orang dari dua kelas sosial yang berbeda. Kedua, orang merasa dirinya menempati posisinya yang inferior atau

\footnotetext{
10 Bilson Simamora, Panduan Riset Perilaku Konsumen (Jakarta: Gramedia Pustaka Utama, 2002), 2

${ }^{11}$ Agung Suprayitno, "Pengaruh Faktor Budaya, Sosial, Pribadi dan Psikologis Konsumen Terhadap Pembelian Gado-Gado Boplo," Jurnal Agribisnis, No. 2 (2015), 201.

12 Bilson Simamora, Panduan Riset Perilaku Konsumen (Jakarta: Gramedia Pustaka Utama, 2002 ), 7.
} 
Rindi Antika, Rohmawati Solikhah : Pengaruh Pembiayaan Murabahah ...

superior dikelas sosial mereka. Ketiga, kelas sosial ditandai oleh sekumpulan variabelvariabel seperti: pekerjaan, penghasilan, kesejahteraan, pendidikan dan orientasi nilai bukan satu variabel. Keempat, individu dapat pindah dari satu tangga ke tangga lain pada kelas sosialnya selama masa hidup mereka.

b) Faktor Sosial

Menurut Kotler dan Keller (2012) faktor sosial seperti kelompok sosial, keluarga serta peranan dan status sosial merupakan aspek eksternal yang menstimulasi keputusan pengambilan keputusan konsumen. ${ }^{13}$ Dengan demikian dapat dikatakan bahwa pengertian sosial adalah semua tingkah laku manusia yang menggambarkan interaksi antar individu manusia dengan manusia lainnya.

Selain faktor budaya, perilaku konsumen juga dipengaruhi oleh faktor- faktor sosial seperti:

Kelompok acuan seseorang terdiri dari semua kelompok yang memiliki langsung (tatap muka) atau tidak langsung terhadap sikap atau perilaku orang tersebut. Kelompok yang memiliki pengaruh langsung terhadap seseorang dinamakan kelompok keanggotaan. Beberapa kelompok keanggotaan merupakan kelompok primer seperti keluarga, teman, tetangga, dan rekan kerja yang berinteraksi dengan seseorang secara terus- menerus dan informal. Orang juga menjadi anggota kelompok sekunder, seperti kelompok keagamaan, profesi, dan asosiasi kelompok perdagangan, yang cenderung lebih formal dan membutuhkan interaksi yang tidak begitu rutin.

Anggota keluarga pembeli dapat memberikan pengaruh yang kuat terhadap perilaku pembeli. Keluarga orientasi adalah keluarga yang terdiri dari orang tua yang memberikan arah dalam hal tuntunan agama, politik, ekonomi dan harga diri. Bahkan jika pembeli tidak berhubungan lagi dengan orang tua, pengaruh terhadap perilaku pembeli tetap ada. ${ }^{14}$

Peran dan status seseorang berpartisipasi dalam banyak kelompok sepanjang hidupnya, keluarga, club, dan organisasi. Kedudukan orang itu masing- masing kelompok dapat ditentukan berdasarkan peran dan statusnya. Peran meliputi kegiatan yang diharapkan akan dilakukan seseorang. Masing-masing peran menghasilkan status. Seorang wakil dirut pemasaran senior memiliki status yang lebih tinggi dari pada manajer penjualan. Orang-orang memilih produk yang dapat mengomunikasikan peran dan status mereka dimasyarakat.

c) Faktor Pribadi

Kepribadian dapat didefinisikan sebagai suatu bentuk dari sifat-sifat yang ada pada diri individu yang sangat menentukan perilakunya. Kepribadian konsumen sangat ditentukan oleh faktor internal dirinya (motif, IQ, emosi, cara berpikir, persepsi) dan faktor eksternal dirinya (lingkungan fisik, keluarga, masyarakat, sekolah, lingkingan alam). Kepribadian konsumen akan mempengaruhi persepsi dan pengambilan keputusan dalam membeli.

Kepribadian sering diartikan sebagai karakteristik individual yang merupakan perpaduan dari sifat, tempramen, kemampuan umum dan bakat yang dalam perkembangannya dipengaruhi oleh interaksi individu dengan lingkungannya. Perilaku seseorang dalam membeli sesuatu juga dipengaruhi oleh faktor-faktor kepribadian dari konsumen yang bersangkutan. Faktor pribadi termasuk watak dasar seseorang

\footnotetext{
${ }^{13}$ Andi Faisal Bahari dan Muhammad Ashoer, "Perngaruh Budaya, Sosial, Pribadi dan Psikologis Terhadap Keputusan Pembelian Konsumen Ekowisata”, Jurnal Manajemen, No. 1 (2018), 4.

14 Bilson Simamora, Panduan Riset Perilaku Konsumen (Jakarta: Gramedia Pustaka Utama, 2002 ), 9.
} 
Rindi Antika, Rohmawati Solikhah : Pengaruh Pembiayaan Murabahah ...

terutama karakteristik dominan mereka. Meskipun kepribadian adalah salah satu konsep yang berguna dalam mempelajari perilaku konsumen, beberapa pemasar percaya bahwa kepribadian mempengaruhi jenis- jenis dan merek-merek produk yang dibeli. ${ }^{15}$

Keputusan membeli juga dipengaruhi oleh karakteristik pribadi. Karakteristik tersebut meliputi: usia dan tahap dalam siklus hidup, pekerjaan, keadaan ekonomi, kepribadian dan konsep diri, serta nilai dan gaya hidup pembeli. Karena banyak karakteristik, memiliki dampak langsung pada prilaku konsumen penting bagi pemasar untuk mengikuti mereka.

Gaya hidup dan nilai. Gaya hidup orang-orang yang berasal dari subbudaya, kelas sosial, dan pekerjaan yang sama bisa saja berbeda. Gaya hidup adalah pola hidup seseorang yang dapat dilihat pada aktivitas, minat dan opininya. Gaya hidup menggambarkan kepribadian seseorang yang berinteraksi dengan lingkungannya Para pemasar mencari hubungan antara produk mereka dengan gaya hidup seseorang.

Keputusan konsumen juga dipengaruhi oleh sistem kepercayaan yang melandasi sikap dan perilaku konsumen. Nilai inti itu jauh lebih dalam daripada perilaku atau sikap, dan pada dasarnya menentukan pilihan dan keinginan orang dalam jangka panjang. Pemasar juga menargetkan konsumen berdasarkan pada keyakinan nilai mereka dengan menarik bagi inner selves mereka.

d) Faktor Psikologis

Faktor psikologis sebagai bagian dari pengaruh lingkungan dimana ia bertempat tinggal dan hidup pada waktu sekarang tanpa mengabaikan pengaruh dimasa lampauatau antisipasinya pada waktu yang akan datang. Schiffman dan Kanuk menyatakan bidang psikologi menggambarkan pengaruh internal (yang meliputi motivasi, kepribadian, persepsi, belajar dan sikap) yang mempengaruhi proses keputusan konsumen.

Proses psikologi utama. Titik awal untuk memahami perilaku konsumen adalah model tanggapan. Pemasaran dan rangsangan lingkungan memasuki kesadaran konsumen. Satu perangkat proses psikologi berkombinasi dengan karakteristik konsumen tertentu untuk menghasilkan proses keputusan dan keputusan pembelian. Tugas pemasar adalah memahami apa yang terjadi dalam kesadaran konsumen antara datangnya rangsangan pemasaran luar dan keputusan pembelian akhir. Empat proses psikologi penting: motivasi, persepsi, pembelajaran dan memori mempengaruhi tanggapan konsumen terhadap berbagai tanggapan pemasaran. ${ }^{16}$

\section{Konsep Dasar Bank Syariah}

Bank Syariah dirancang untuk terbinanya kebersamaan dalam menanggung risiko usaha dan berbagi hasil usaha antara : pemilik dana (shahibul maal) yang menyimpan uangnya di bank dengan bank selaku pengelola dana (mudharib). Dan di sisi lain bank selaku pemilik dana dengan masyarakat yang membutuhkan dana baik yang berstatus pemakai dana maupun pengelola usaha (mudharib).

Pada sisi pengerahan dana masyarakat (funding), pemilik dana (shahibul maal) berhak atas bagi hasil dari usaha Bank sesuai dengan porsi yang telah disepakati

\footnotetext{
15 Tatik Suryani, Perilaku Konsumen: Implikasi pada Strategi Pemasaran, (Yogyakarta: Graha Ilmu, 2012), 57

${ }^{16}$ Ketut Indah P. dan Kastawan M., "Pengaruh Faktor Budaya, Sosial, Pribadi Psikologis dan Bauran Pemasaran Terhadap Keputusan Pembelian Kebaya Bordir pada Jegeg Ayu Boutique di Kuta", Jurnal Manajemen Unud, No. 11 (2015), 3622.
} 
bersama. Bagi hasil yang diterima pemilik dana (shahibul maal) akan naik-turun secara wajar sesuai dengan keberhasilan usaha Bank dalam mengelola dana yang dipercayakan kepadanya. Tidak ada biaya yang perlu dikenakan karena bagi hasil bukan konsep biaya. ${ }^{17}$

Bank selaku mudharib harus dapat mengelola dana yang dipercayakan kepadanya dengan hati-hati (prudent) dan memperoleh penghasilan yang maksimal. Dalam mengelola dana ini, bank mempunyai 4 (empat) jenis pendapatan yaitu : Pendapatan bagi hasil, Margin keuntungan (mark-up harga beli), Imbalan jasa pelayanan, Sewa tempat penyimpanan harta (pada Bank yang telah memenuhi syarat), dan pengembalian biaya administrasi. Dalam bagi hasil besar-kecilnya pendapatan tergantung dari jenis usaha yang dibiayai, jika memberikan porsi bagi hasil yang lebih besar maka akan memotivasi pengelola dana untuk lebih giat berusaha, demikian pula sebaliknya. Oleh karena itu porsi 50:50 dianggap cukup adil.

Lain halnya pada pendapatan mark-up, pilihan terletak pada apakah ingin sekaligus untung besar per transaksi tetapi menjadi mahal dan tidak laku, atau keuntungan per transaksi kecil tetapi dengan volume yang besar karena murah dan laku keras. Pendapatan bank dapat dioptimalkan dengan mengambil kebijakan keuntungan kecil pertransaksi untuk memperbanyak jumlah transaksi yang dibiayai. ${ }^{18}$

\section{Kerangka Pemikiran}

Kerangka pemikiran dalam penelitian ini difokuskan pada pengaruh faktor budaya, faktor sosial, faktor pribadi dan faktor psikologis terhadap keputusan nasabah dalam memilih bank syariah. Berdasarkan landasan teori diatas, maka diperlukan sebuah analisa mengenai bagaimana pengaruh faktor budaya, faktor sosial, faktor pribadi dan faktor psikologis terhadap keputusan nasabah dalam memilih bank syariah. Maka kerangka pemikiran dalam penelitian ini menggunakan analisis regresi berganda, dapat digambarkan sebagai berikut.

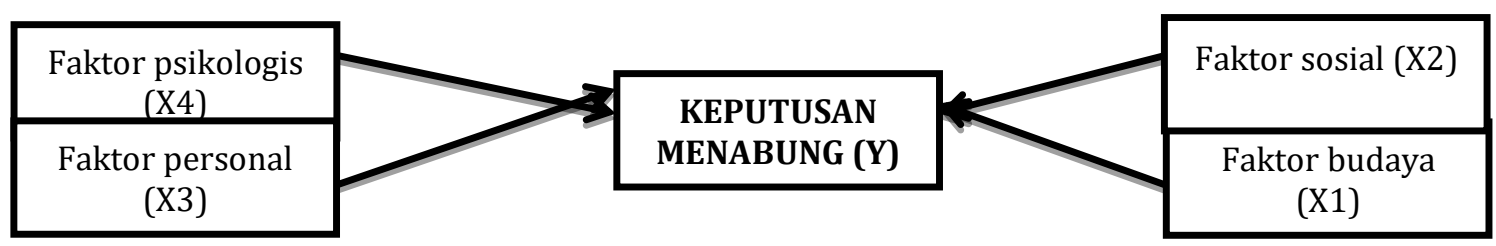

\section{Metode penelitian}

1. Rancangan Penelitian

Dalam rancangan penelitian ini, peneliti menggunakan jenis penelitian kuantitatif, yaitu penelitian yang digunakan untuk meneliti pada populasi dan sampel tertentu. Teknik pengambilan sampel dilakukan random, pengumpulan data menggunakan instrument penelitian, analisis data bersifat kuantitatif statistik dengan tujuan untuk menguji hipotesis yang telah ditetapkan. ${ }^{19}$

2. Variabel Penelitian

Variabel yang digunakan dalam penelitian ini adalah:

\footnotetext{
17 Muhammad Syafi'I Antonio, Bank Syariah Dari Teori ke Praktik (Jakarta: Gema Insani, 2001), 18.

${ }^{18}$ Hendri Tanjung dan Karnaen Perwataatmadja, Bank Syariah (Jakarta: PT. Senayan Abadi, 2007), 75

${ }^{19}$ Sugiyono, metode Penelitian Pendidikan Pendekatan Kuantitatif, Kualitatif dan R\&D (Bandung: Alfabeta, 2011), 91.
} 
a. Faktor budaya (X1), dapat didefinisikan sebagai hasil kreativitas manusia dari satu generasi ke generasi berikutnya yang sangat menentukan bentuk perilaku dalam kehidupannya sebagai anggota masyarakat.

b. Faktor sosial (X2), perilaku seorang konsumen yang dipengaruhi oleh faktor-faktor sosial seperti perilaku kelompok acuan (kelompok referensi), keluarga, serta peran dan status sosial dari konsumen.

c. Faktor personal (X3), keputusan seorang pembeli juga dipengaruhi oleh karakteristik pribadi, yaitu usia pembeli dan tahap siklus hidup pembeli, pekerjaan, kondisi ekonomi. d. Faktor psikologis (X4), pilihan pembelian seseorang dipengaruhi pula oleh empat faktor psikologis utama, yaitu motivasi, persepsi, pengetahuan (learning), serta keyakinan dan sikap.

e. Keputusan (Y) adalah sebuah proses pendekatan penyelesaian masalah yang terdiri dari pengenalan masalah, mencari informasi, beberapa penilaian alternatif, membuat keputusan membeli dan perilaku setelah membeli yang dilalui konsumen.

3. Populasi dan Sampel

a. Populasi, Populasi merupakan jumlah keseluruhan yang mencakup semua anggota yang diteliti. ${ }^{20}$ Populasi dalam penelitian ini adalah seluruh mahasiswa IAIN Ponorogo yang berjumlah 10.349 orang.

b. Sampel, Pengambilan sampel dalam penelitian ini menggunakan metode convenience sampling, yaitu istilah umum yang mencakup variasi luasnya prosedur pemilihan responden. Convenience sampling merupakan unit sampling yang mudah dihubungi, tidak menyusahkan, mudah untuk mengukur, dan bersifat membantu. ${ }^{21}$ Metode convenience sampling digunakan karena peneliti memiliki kebebasan untuk memilih sampel dengan cepat dari elemen populasi yang datanya mudah diperoleh peneliti. Penentuan sampel penelitian ini menggunakan rumus Slovin:22Jumlah sampel yang digunakan dibulatkan yaitu sebesar 100 orang.

\section{Hasil dan Pembahasan}

Dari hasil analisis yang telah dilakukan, pembahasan tentang hasil penelitian ini adalah sebagai berikut:

1. Pengaruh faktor budaya (X1) terhadap keputusan menabung di bank syariah Menurut Kotler (2015) faktor pertama yang mempengaruhi perilaku pengambilan keputusan adalah faktor kebudayaan. Faktor kebudayaan merupakan penentu keinginan dan perilaku yang paling mendasar untuk mendapatkan nilai, persepsi, preferensi dan perilaku dari lembaga-lembaga penting lainnya. Faktor budaya meliputi kebudayaan, sub- budaya dan kelas sosial.

Berdasarkan hasil pengujian menunjukkan bahwa secara parsial variabel budaya (X1) mempunyai pengaruh terhadap variabel keputusan menabung (Y). Hal ini didukung dengan hasil variabel budaya yang mempunyai nilai thitung 2,733 > tabel 1,984 dan signifikansi 0,007 lebih kecil dari 0,05. Berdasarkan nilai kriteria $\mathrm{H}_{\mathrm{O}}$ ditolak dan $\mathrm{Ha}_{a}$ diterima, artinya variabel budaya berpengaruh secara parsial dan signifikan terhadap keputusan menabung sebesar0,301 atau 30,1\% dan sisanya

\footnotetext{
20 Istijanto, Aplikasi Praktis Riset Pemasaran- Cara praktis Meneliti Konsumen dan Pesaing (Jakarta: PT Gramedia Pustaka Utama, 2009), 113.

${ }^{21}$ Abdul Hamid, Buku Panduan Penulisan Skripsi (Jakarta: FEIS UIN Press, 2007), 30,

${ }^{22}$ Ridwan Engkos Ahmad Kuncoro, Cara Menggunakan Analisis Jalur (Path Analisys) (Bandung: Alfa Beta, 2008), 49
} 
Rindi Antika, Rohmawati Solikhah : Pengaruh Pembiayaan Murabahah ...

$69,9 \%$ dijelaskan oleh faktor lain. Variabel budaya dalam penelitian ini menggunakan indicator nilai, persepsi, preferensi, kebudayaan, agama, kelompok ras, wilayah geografis, kelas sosial.

2. Pengaruh faktor sosial (X2) terhadap keputusan menabung di bank syariah

Menurut Kotler dan Keller (2012) faktor sosial seperti kelompok sosial, keluarga serta peranan dan status sosial merupakan aspek eksternal yang menstimulasi keputusan pengambilan keputusan konsumen. Dengan demikian dapat dikatakan bahwa pengertian sosial adalah semua tingkah laku manusia yang menggambarkan interaksi antar individu manusia dengan manusia lainnya. Keinginan seseorang pada suatu produk juga umumnya dipengaruhi oleh faktor sisoal ini.

Berdasarkan hasil pengujian menunjukkan bahwa secara parsial variabel sosial $\left(\mathrm{X}_{2}\right)$ mempunyai pengaruh terhadap variabel keputusan menabung (Y). Hal ini didukung dengan hasil variabel sosial yang mempunyai nilai thitung 2,360 $>$ tabel 1,984 dan signifikansi 0,020 lebih kecil dari 0,05. Berdasarkan nilai kriteria $\mathrm{H}_{\mathrm{O}} 2$ ditolak dan $\mathrm{H}_{\mathrm{a}}$ diterima, artinya variabel sosial berpengaruh secara parsial dan signifikan terhadap keputusan menabung sebesar 0,357 atau 35,7\% dan sisanya 64,3\% dijelaskan oleh faktor lain. Variabel sosial dalam penelitian ini menggunakan indicator sikap, perilaku, kebiasaan, orang tua, kerabat terdekat, posisi dan jabatan.

3. Pengaruh faktor personal (X3) terhadap keputusan menabung di bank syariah Kepribadian sering diartikan sebagai karakteristik individual yang merupakan perpaduan dari sifat, tempramen, kemampuan umum dan bakat yang dalam perkembangannya dipengaruhi oleh interaksi individu dengan lingkungannya. Perilaku seseorang dalam membeli sesuatu juga dipengaruhi oleh faktor-faktor kepribadian dari konsumen yang bersangkutan. Faktor pribadi termasuk watak dasar seseorang terutama karakteristik dominan mereka. Meskipun kepribadian adalah salah satu konsep yang berguna dalam mempelajari perilaku konsumen, beberapa pemasar percaya bahwa kepribadian mempengaruhi jenis-jenis dan merek-merek produk yang dibeli.

Berdasarkan hasil pengujian menunjukkan bahwa secara parsial variabel personal (X3) tidak mempunyai pengaruh terhadap variabel keputusan menabung (Y). Hal ini karena dengan hasil variabel personal yang mempunyai nilai thitung 1,092< ttabel 1,984 dan signifikansi 0,277 lebih besar dari 0,05. Berdasarkan nilai kriteria $\mathrm{H}_{\mathrm{O} 3}$ diterima dan $\mathrm{H}_{\mathrm{a}}$ ditolak, artinya variabel personal tidak berpengaruh secara parsial dan signifikan terhadap keputusan menabung.

4. Pengaruh faktor psikologis (X4) terhadap keputusan menabung di bank syariah Faktor psikologis sebagai bagian dari pengaruh lingkungan dimana ia bertempat tinggal dan hidup pada waktu sekarang tanpa mengabaikan pengaruh dimasa lampauatau antisipasinya pada waktu yang akan datang. Schiffman dan Kanuk menyatakan bidang psikologi menggambarkan pengaruh internal (yang meliputi motivasi, kepribadian, persepsi, belajar dan sikap) yang mempengaruhi proses keputusan konsumen.

Berdasarkan hasil pengujian menunjukkan bahwa secara parsial variabel psikologis (X4) mempunyai pengaruh terhadap variabel keputusan menabung (Y). Hal ini dibuktikan dengan hasil variabel psikologis yang mempunyai nilai thitung 2,330> ttabel 1,984 dan signifikansi 0,022 lebih kecil dari 0,05. Berdasarkan nilai kriteria $\mathrm{H}_{\mathrm{O}} 4$ ditolak dan $\mathrm{H}_{\mathrm{a}}$ diterima, artinya variabel personal berpengaruh secara parsial dan signifikan terhadap keputusan menabung. Variabel psikologis dalam penelitian ini 
Rindi Antika, Rohmawati Solikhah : Pengaruh Pembiayaan Murabahah ...

menggunakan indicator kebutuhan, pengalaman dan iklan.

5. Pengaruh faktor budaya, sosial, personal dan psikologis terhadap keputusan menabung.

Berdasarkan pengujian secara simultan menunjukkan bahwa variabel X berpengaruh positif dan signifikan terhadap variabel Y. berdasarkan hasil uji F secara simultan menunjukkan bahwa secara bersama-sama variabel X menujukkan hasil yang positif terhadap keputusan menabung yaitu dapat ditunjukan melalui penghitungan uji $\mathrm{F}$ yaitu Fhitung 22,440 > Ftabel 2,71 dan nilai signifikansi 0,000 < 0,05. Berdasarkan nilai kriteria $\mathrm{H}_{05}$ ditolak dan $\mathrm{H}_{\mathrm{a}} 5$ diterima, dan nilai koefisien determinasi $\mathrm{R}(R$ Square) sebesar 0,486 sehingga variabel independen dapat menjelaskan variabel dependen sebesar 48,6\% dan sisanya yaitu sebesar $51,4 \%$ dijelaskan oleh faktor lain.

\section{E. Kesimpulan}

Berdasarkan analisis data dan pembahasan mengenai variabel budaya, sosial, personal, dan psikologis terhadap keputusan menabung dapat diambil kesimpulan sebagai berikut:

1. Variabel budaya berpengaruh secar signifikan terhadap minat menabung di bank syariah.

2. Variabel sosial berpengaruh secara signifikan terhadap minat menabung di bank syariah.

3. Variabel personal tidak berpengaruh secara signifikan terhadap minat menabung di bank syariah.

4. Variabel psikologis berpengaruh secara signifikan terhadap minat menabung di bank syariah.

5. Variabel X berpengaruh positif dan signifikan terhadap variabel Y. berdasarkan hasil uji $\mathrm{F}$ secara simultan menunjukkan bahwa secara bersama-sama variabel $\mathrm{X}$ menujukkan hasil yang positif terhadap keputusan menabung yaitu dapat ditunjukan melalui penghitungan uji F yaitu Fhitung 22,440 > Ftabel 2,71 dan nilai signifikansi $0,000<0,05$. Berdasarkan nilai kriteria $\mathrm{H}_{05}$ ditolak dan $\mathrm{H}_{\mathrm{a}} 5$ diterima, dan nilai koefisien determinasi $\mathrm{R}$ ( $R$ Square) sebesar 0,486 sehingga variabel independen dapat menjelaskan variabel dependen sebesar $48,6 \%$ dan sisanya yaitu sebesar 51,4\% dijelaskan oleh faktor lain.

\section{Daftar Pustaka}

Antonio, Muhammad Syafi'I. Bank Syariah Dari Teori ke Praktik (Jakarta: Gema Insani, 2001)

Bahari, Andi Faisal. Ashoer, Muhammad, "Perngaruh Budaya, Sosial, Pribadi dan Psikologis Terhadap Keputusan Pembelian Konsumen Ekowisata”, Jurnal Manajemen, No. 1 (2018), 4.

Effendi, Usman. Psikologi Konsumen (Jakarta: PT. Rajagrafindo Persada, 2016), 247

Firmansyah, M. Anang. PERILAKU KONSUMEN (Sikap dan Pemasaran) (Yogyakarta: Deepublish, 2018)

Hamid, Abdul, Buku Panduan Penulisan Skripsi (Jakarta: FEIS UIN Press, 2007), 30,

Indah P. Ketut, dan Kastawan M., "Pengaruh Faktor Budaya, Sosial, Pribadi Psikologis dan Bauran Pemasaran Terhadap Keputusan Pembelian Kebaya 
Rindi Antika, Rohmawati Solikhah : Pengaruh Pembiayaan Murabahah ...

Bordir pada Jegeg Ayu Boutique di Kuta", Jurnal Manajemen Unud, No. 11 (2015), 3622.

Istijanto, Aplikasi Praktis Riset Pemasaran- Cara praktis Meneliti Konsumen dan Pesaing (Jakarta: PT Gramedia Pustaka Utama, 2009), 113.

Kuncoro, Mudrajad. Metode Riset untuk Bisnis dan Ekonomi (Jakarta: Erlangga, 2003)

Kuncoro, Ridwan Engkos Ahmad. Cara Menggunakan Analisis Jalur (Path Analisys) (Bandung: Alfa Beta, 2008), 49

Nugroho J. Setiadi, Perilaku Konsumen: Perspektif Kontemporer pada Motif, Tujuan dan Keinginan Konsumen (Jakarta: Predamedia Group, 2003), 345.

Simamora, Bilson, Panduan Riset Perilaku Konsumen (Jakarta: Gramedia Pustaka Utama, 2002), 2

Sugiyono, Metode Penelitian Pendidikan (Pendekatan Kuantitatif, Kualitatif dan R\&D) (Bandung: Alfabeta, 2008), 162.

Suprayitno, Agung, "Pengaruh Faktor Budaya, Sosial, Pribadi dan Psikologis Konsumen Terhadap Pembelian Gado-Gado Boplo," Jurnal Agribisnis, No. 2 (2015)

Suryani, Tatik. Perilaku Konsumen: Implikasi pada Strategi Pemasaran, (Yogyakarta: Graha Ilmu, 2012)

Tanjung, Hendri. Perwataatmadja, Karnaen Bank Syariah (Jakarta: PT. Senayan Abadi, 2007), 75

Yulaifah, Atin, "Pengaruh Budaya, Sosial, Pribadi, dan Psikologis Terhadap Keputusan Nasabah Dalam Memilih Bank Syariah", Skripsi (Jakarta: UIN Syarif Hidayatullah, 2011), 23. 